\title{
PRE-SERVICE TEACHERS' TEACHING SKILLS, ENGLISH PROFICIENCY, INTERCULTURAL SENSITIVITY, EXPOSURE TO FOREIGN CULTURE ACROSS L2 ENVIRONMENTS
}

\author{
Susilo Susilo \\ Mulawarman University, Indonesia \\ Email: olisusunmul@gmail.com
}

DOI: $10.26858 /$ ijole.v1i1.6929

\begin{abstract}
This was a survey study involving 156 pre-service teachers taken from three local universities in Indonesia, investigating whether or not different L2 learning environment of English teacher education affect the NNES pre-service teachers' teaching skills, intercultural sensitivity, exposure to foreign culture, and English proficiency. The data were collected through observation scaling checklist, and 2) questionnaire. Descriptive analysis and a series of one-way ANOVA were used to analyze the data. The results showed that: 1) the effect of L2 learning environments on teaching skills was not significant $F$ $(2)=2.831 ., p=0.062 ; 2)$ the effect of L2 learning environments on intercultural sensitivity was not significant $F(2)=4.991, p=0.008 ; 3)$ the effect of L2 learning environments on exposure to foreign culture was not significant $F(2)=1.577, p=0.210$., and 4) the effect of L2 learning environments on English proficiency was significant $F(2)=56.153, p=0.000$.
\end{abstract}

Keywords: NNES pre-service teachers, teaching skills, intercultural sensitivity, exposure to foreign culture, and English proficiency

\section{INTRODUCTION}

Public perception of the native speaker's role in English language teaching (ELT) has changed, being close to an egalitarian view where everybody agrees that the role of nonnative English speaking teachers (NNESTs) is as important as that of the native English speaking teachers (NESTs). Issue of the comparison between NNESTs and NESTs two decades ago highlighted NNESTs' shortage in terms of linguistic knowledge, proficiency, and teaching competence as well (Stern, 1983; McNeill, 1993; Milambiling, 1999; Samimy and Brutt-Griffler, 1999) compared to NESTs who were assumed to be strong cultural resources and thus more proficient L2 teachers (e.g. Árva \& Medgyes, 2000; Carless, 2006). However, nowadays NNESTs and NESTs academically have the same potentials, e.g. questionable guarantee of native speakers' authority and ownership of English (Pasternak and Bailey, 2004), and native speaker's inability to identify context of learners and establishing empathy when they are teaching (Seidlhofer, 1999; Árva \& Medgyes, 2000; Barratt \& Kontra, 2000); or the apparent domination of nonnative speakers of English in global communication (Alptekin, 2002; Jenkins, 2000; Kirkpatrick, 2006) contributing greatly to the changing public assumptions about English learning.

Given a condition where NNESTs is getting a significant role in ELT area, there is a need to have a look at the L2 teacher education in non-English speaking countries as the formal producers of NNESTs. As a matter of fact, institutionally the NNESTs' teaching skills have been gained through teaching skill courses in the curriculum offered by the L2 teacher 
educations, while in any cases, the skills were partly determined by the NNESTs' English proficiency which has been dependent to some extent on how much English they acquire during their study in the institution. Obviously, to get adequate proficiency in English, it is not enough for pre-service teachers to only formally learn it from the courses offered by the syllabus; they also have to gain some exposure to foreign cultures outside the class (e.g. interacting with English native speakers, reading English magazines, watching English TV channels, movies, music, etc.) in order to maximize the attainment of their L2 acquisition. To do so, they need intercultural sensitivity, which is required for successful and productive communication among people from different cultural backgrounds (Chen \& Starosta, 1997; Graf, 2004; Moran, et.al., 2007; Olson \& Kroeger, 2001; Rosen et al., 2000).

There have been more evidences supporting the fact that the teacher's role in teaching and students' achievements have a strong relationship (e.g. Andrew, et al., 2005; 1998; Zaharah, 2014; Sanders, 1998, 2000; Wright, et al., 1997; Conti \& Welborn, 1996; Jarvis, 2004). Producing qualified NNESTs to teach English in a wide range of non-English speaking regions can presumably be a panacea for present difficulties in accomplishing better results in EFL teaching. It is then the job of English teacher educations to guarantee the quality of NNESTs; thus, to achieve improvement in the outcomes of ELT needs the improvement of these English language teacher education institutions' performance. For English teacher education in Indonesia, the direction of the university curriculum should be set by regulations issuing from the Ministry of Research, Technology and Higher Education. The higher education curricula used by all Indonesian universities to determine their learning outcomes should be fitted to the nine levels of qualifications stipulated that country's Qualification Framework; however, each university has the freedom to create the content of the curriculum in order that their graduates can be competitive in the labor force (Susilo, 2015). Thus, the university governance system of each English teacher education institution in Indonesia apparently determines the extent of attainment of the students' teaching skills and English proficiency. Since university governance in Indonesia is extremely different from university in one region to university in another region, - all English teacher education institutions in Indonesia are under different university governance -, then it is paramount that such different university governance can imply different quality of their students.

Given the condition above, English pre-service teachers are growing up in different in-campus environments. Specifically, for English teacher education institutions in Indonesia, Littlewood's (2005) four aspects of learning environments in achieving L2 proficiency, i.e. opportunities to use L2, emotional climate of learning situation, learner's linguistic input, and formal instruction, are given differently due to different condition of the university governance; consequently, different effects might be given to the English pre-service teachers because of their being from different campuses. Some research findings reveal powerful effects of learning environments on learning motivation; while learning motivation is evidently proved as the influencing factor to achieve satisfying learning goals in learning (see Chua, et al., 2011; Ghenghesh, 2010; Lamb, 2011; Wang, 2010).

Alongside the rapid development of technology and media, the challenges faced by institutions of teacher education have been as equally tough as the challenges encountered by teachers. The fact that the need of English teachers in non-English speaking countries increases as a consequence of English being used as a global lingua franca triggers the such 
institutions to have the obligations to produce huge numbers of NNESTs. In addition, new paradigm of language teaching in the $21^{\text {st }}$ century requires the English teacher educations to give more space to multicultural aspects in equipping their NNEST teacher candidates (i.e. preservice teachers) with global competence. Even some experts on L2 teacher education argue that recently there has been a shift of the main goal of L2 teacher education from the traditional approach of teaching to the situated and social nature of pre-service teachers' L2 learning (Lave and Wenger, 1991; Johnson, 2009), learning L2 as a means of mediating thinking (Vygotsky, 1978; Leont'ev, 1981), and focusing on function in learning L2 (Gee, 1996; Bakhtin, 1981). As summarized by Freeman and Johnson (1998), the importance of pre-service teachers' L2 acquisition should be highlighted in the process of teaching and learning in English teacher education. Therefore, English proficiency, teaching skills, and competence to face different cultures in order to seek out more exposure to foreign culture become extremely important.

This current study aims at investigating whether or not in-campus L2 environment affect the NNES pre-service teachers' teaching skills, intercultural sensitivity, L2 exposure to foreign culture, and English proficiency.

\section{METHODOLOGY}

\section{Participants}

Participants of the current study were 156 pre-service teachers (i.e. students in the faculty of teacher training and education) taken from three local universities in Indonesia, i.e. Mulawarman, Borneo Tarakan University, and Widyagama Mahakam University. Each university was represented by 52 students who were chosen randomly from the population of all students in L2 teacher education who met certain criteria (see table 1). The criteria were: 1) those who have teaching experiences in schools or English courses, 2) those who have taken the micro teaching course, and 3) those who have taken the internship program as a part of the prerequisite credits for accomplishing undergraduate program of English language education. In addition, the participants have provided their informed consent in accordance with research ethics.

\section{Instrument}

There were three instruments used in the present study, i.e. 1) observation scaling checklist, 2) questionnaire, and 3) TOEFL-equivalent test. The observation scaling checklist was used for assessing the respondents' performance when they were doing teaching practice internships in schools. Each respondent was assessed by the researchers' team using the checklist in which four scales $(1-4)$ were used as the options of performance in each aspect of teaching. It was designed by firstly developing concept of teaching skills (Cooper, 2011; Burns \& Richards, 2009; Hedge, 2008; Ur, 2010); then divide the concept into three aspects, i.e. teaching preparation, teaching action and teaching evaluation. Meanwhile, the questionnaire was designed by developing concepts of $L 2$ Exposure to foreign culture was developed from Norries \& Gillespie (2009) and Sodnomdarja (2006). In the meantime, the concept of intercultural sensitivity was adapted from Bennett's Developmental Model of Intercultural Sensitivity or DMIS (Bennett, 1993; Paige, et. al., 2003; Hammer, et.al., 2003; Olson \& Kroeger, 2001; Jeon, \& Lee, 2017). The questionnaire consisted of 20 close-ended questions with four-point Likert scale (i.e. strongly agree, agree, disagree and strongly disagree), including 12 items asking about intercultural sensitivity, and 8 items asking about exposure to foreign culture.

Internal consistency of each concept in the questionnaire was examined by using Cronbach Alpha (see Cronbach Alpha indices per concept in table 2). 
Before being distributed for completion, the questionnaire was piloted to 20 fourth-semester students of the faculty of teacher training, Mulawaman University for the purpose of identifying unclear or ambiguous items. Based on the results of the piloting, the questionnaire was revised before it was launched for data collection. In order to obtain the complete comprehension of the participants, the L1 of Indonesia was used for the wording of the questionnaire. The scores of English proficiency was taken from the students' TOEFL scores as a result of TOEFLequivalent test conducted prior to the study.

\section{Data Collection and Analysis}

For collecting the data of intercultural sensitivity, and exposure to foreign culture, the questionnaire was distributed to the respondents; while for the data of respondents' teaching skills were elicited by using scaling checklist; and in collecting the data of English proficiency, respondents' scores on TOEFL-equivalent tests were used. The process of completing the questionnaire was done under the close supervision of enumerators to ensure the respondents' seriousness in answering the questions and to avoid misinterpretation. The data analysis was done quantitatively, i.e. by using the SPSS program. Descriptive statistics (i.e. to know the minimum and maximum score and the mean of the items answered in the questionnaire), and a series of one-way ANOVA) were used.

\section{Hypothesis of the Study}

There were 4 research hypotheses

(Ha) used in the study, namely:

1. There are differences in teaching skills performed by NNES pre-service teachers across in-campus L2 environments

2. There are differences in intercultural sensitivity possessed by NNES preservice teachers across in-campus L2 environments

3. There are differences in exposure to foreign culture gained by NNES preservice teachers across in-campus L2 environments

There are differences in English proficiency achieved by NNES pre-service teachers across in-campus L2 environments

\section{RESULTS AND DISCUSSIONS}

\section{Results}

A one-way ANOVA was conducted to know whether there are differences in NNES pre-service teachers' teaching skills, intercultural sensitivity, exposure to foreign culture, and English proficiency across L2 environments. First, as shown in table 3, Unmul $(M=31.53, S D=3.35)$, Uwgm $(M$ $=32.96, S D=3.44)$, and Ubt $(M=31.88$, $S D=2.68)$ did not differ significantly on their NNES pre-service teachers' teaching skills, $F(2)=2.831, p=0.062$. (see table $3)$. It means that there was no significant difference among teaching skills of NNES pre-service teachers across three in-campus L2 environments.

Second, as seen in table 4, Unmul $(M=34.11, S D=3.22), \operatorname{Uwgm}(M=36.03$, $S D=3.41)$, and Ubt $(M=35.26, S D=2.67)$ did not differ significantly on their NNES pre-service teachers' intercultural sensitivity, $F(2)=4.991, p=0.008$. This means there was no significant difference in the intercultural sensitivity possessed by NNES pre-service teachers across L2 environments.

Third, Unmul $(M=19.288, S D=$ 3.19), Uwgm $(M=20.34, S D=3.23)$, and Ubt $(M=19.67, S D=2.77)$ did not differ significantly on their NNES pre-service teachers' exposure to foreign culture, $F(2)$ $=1.577, p=0.210$ (see table 5). It means that there was no significant difference among NNES pre-service teachers' exposure to foreign culture across L2 environments.

Fourth, as shown in table 6, Unmul $(M=487, S D=29.34)$, Uwgm $(M=424$, $S D=19.50)$, and Ubt $(M=445, S D=39.35)$ differ significantly on their NNES preservice teachers' English Proficiency, $F$ (2) $=56.153, p=0.000$. It means that there was significant difference in NNES pre-service 
teachers' English proficiency across L2 environment.

\section{Discussion}

The finding reveals that there is no significant effect of differences in the incampus L2 environments of English teacher educations on NNES pre-service teachers' teaching skills, intercultural sensitivity, and exposure to foreign culture. Regarding this finding, various explanations can be proposed in connection with these three variables.

First, in the context of Indonesian higher education, even though every university has the freedom to create the content of the curriculum in order that their graduates can be competitive in the labor force, curricula used by all universities in general follow the standardized learning outcomes stipulated by Indonesian Qualification Framework (Susilo, 2015). Obviously, faculties of teacher training educations have to set up common contents of teaching skill courses, implying common L2 environments for the pre-service teachers. Furthermore, a short of teaching skills are proved to be different from novice teachers and experienced teachers; e.g. studies highlighting the typical ways in which such skills are developed and displayed by beginning teachers and how experienced teachers think about the skills they use in teaching (Wragg, 2005; Day, 2004; Pollard et al., 2005). In line with this, what ever the L2 environment is set up, it does not play a significant role in constructing teaching skill. Therefore, it is not surprising that teaching skills from the NNES pre-service teachers from teacher educations under study are not significantly different.

Second, in respect of intercultural sensitivity, even though courses containing intercultural sensitivity have not been formally stipulated in the curricula of all teacher training faculties, almost all L2 content courses of the EFL teacher training curriculum encapsulate authentic materials which are foreign-culture bound.
Therefore, Littlewood's (2005) four aspects of learning environments - opportunities to use L2, emotional climate of learning situation, learner's linguistic input, and formal instruction - are similarly designed institutionally in accordance with such foreign-cultural bound materials. As a consequence, this leads to the fact that all NNES pre-service teachers have relatively the same understanding of intercultural sensitivity. In addition, research findings assert that it is the learning motivation on which the effect of learning environments significantly give, not the intercultural sensitivity (see Chua, et al, 2011; Ghenghesh, 2010; Lamb, 2011; Wang, 2010). Besides, regarding the exposure to foreign culture, since the English teacher education institutions under study are located in relatively the same EFL environments (i.e. the location of ELT in an expanding circle context), then the exposure to foreign culture gained by the NNES pre-service teachers is relatively the same. Obviously, NNES pre-service teachers' intercultural sensitivity and exposure to foreign culture under study are not significantly different even though they learn under different institutional managements.

However, for the English proficiency, this study finds a different result, i.e. there is a significant effect of different institutional locality on preservice teachers' English proficiency. This result is in line with the notion that NNES pre-service teachers' English proficiency is basically dependent on many things: among others are human resources (teaching staff or administration staff), teaching facilities (such as laboratory, media, or teaching materials), which vary among institutions. Theoretically, SLA variability has been to some extent dependent on a number of factors, such as modes of L2 acquisition immersion vs. classroom (e.g., Carroll, 1967), length of L2 immersion (e.g., Flege, et.al., 1997), or extent of daily L2 vs. L1 usage (e.g., Jia et al., 2002). L2 exposure has been assumed efficient in order for non- 
native English learners to increase their L2 proficiency. Furthermore, evidently L2 exposure and the attainment of L2 proficiency have been demonstrated by many studies, e.g. the relationship between the age at which a learner is exposed to L2 and the ultimate L2 attainment level (Birdsong, 2005; Birdsong \& Molis, 2001; Johnson \& Newport, 1989); the benefits of the degree to which a learner is immersed in L2 (Carroll, 1967; Flege et al., 1999); the extent of L2 exposure (Birdsong, 2005; Genesee, 1985; Kohnert, et.al., 1999; Weber-Fox \& Neville, 1999); and the extent of on-going L2 use (Flege, et.al., 2002; Jia et al., 2002). Therefore, it is presumable that different human resources and the quality of teaching staff in these incampus L2 learning environments of English teacher education institutions influence differences of the English proficiency achieved by their pre-service teachers.

\section{CONCLUSIONS}

There are four conclusions which can be drawn from the result. Firstly, in terms of teaching skills, the result shows that the effect of in-campus L2 environments of English teacher education institutions were not significant $F(2)=$ $2.831, p=0.062$. Secondly, for intercultural sensitivity, the result of the study reveals that the effect of different in-campus L2 environments of English teacher education institutions were not significant $F(2)=$ 4.991, $p=0.008$. Thirdly, the finding tells that the effect of different in-campus L2 environments of English teacher education institutions was not significant $F(2)=$ $1.577, p=0.210$. Finally, the effect of incampus L2 environments of English teacher education institutions were significant $F(2)=56.153, p=0.000$.

\section{REFERENCES}

Alptekin, C. (2002). Towards intercultural communicative competence ELT. ELT Journal, 56 (1), 57-64. doi.org/10.1093/elt/56.1.57

Andrew, D., Cobb, Casey D., \& Giampietro, Peter J. 2005. Verbal Ability and Teacher effectiveness. Journal of Teacher Education. 56 (4): 343-354.

https://doi.org/10.1177/00224871052 79928

Árva, V., \& Medgyes, P. (2000). Native and non-native teachers in the classroom. System, 28: 355-372 doi.org/10.1016/S0346251X(00)00017-8

Barratt, L., \& Kontra, E. (2000). Native English-speaking teachers in cultures other than their own. TESOL Journal, 9 (3): 19-23. doi: 10.12691/education-5-12-2

Bennett, J. M. (1993). Toward ethnorelativism: A developmental model of intercultural sensitivity. In R. M. Paige (Ed.), Education for the intercultural experience (pp. 21-71). Yarmouth, ME: Intercultural.

Bhaktin, M. (1981). The Dialogic Imagination: Four Essays by $M$. Bhaktin. Austin: University of Texas Press.

Birdsong, D. (2005). Interpreting age effects in second language acquisition. In J. Kroll \& A. DeGroot (eds.), Handbook of Bilingualism: Psycholinguistic Perspectives (pp.109-127). Oxford: Oxford U. Press.

Birdsong, D., \& Molis, M. (2001). On the evidence for maturational effects in second language acquisition. Journal of Memory and Language, 44: 235 249. doi:10.1006/jmla.2000.2750

Burns, A. \& Richards, J. K. (2009). Second Language Teacher Education. (eds). Cambridge: Cambridge University Press.

Carless, D. (2006). Collaborative EFL teaching in primary schools. ELT Journal, $\quad$ 60(4): 328-335. 
doi: http://dx.doi.org/10.1093/elt/ccl 023

Carroll, J. (1967). The foreign language attainments of language majors in the senior year: A survey conducted in U.S. colleges and universities. Cambridge, MA: Harvard University Press.

Chen, G. M., \& Starosta, W. J. (1997). A review of the concept of intercultural sensitivity. Human Communication, 1: 1-16. (online:

http://digitalcommons.uri.edu/com_f acpubs)

Conti, G. \& Welborn, R. (1996). Teaching learning styles and the adult learner. Lifelong Learning, 9 (8): 2024

Cooper, J. M. (2011).( $9^{\text {th }}$. Ed). Classroom Teaching Skills. Belmont, CA: Wadsworth, Cengage Learning.

Chua, S. L., Wong, A. F. L., \& Chen, D. (2011). The nature of Chinese language classroom learning environments in Singapore secondary schools. Learning Environment Research, 14, 75-90. DOI 10.1007/s 10984-011-9084-0

Day, C. (2004). A Passion for Teaching. London: Routledge Falmer

Flege, J. E., Yeni-Komishian, G. H., \& Liu, S. (1999)." Age constraints on second language acquisition".

Journal of Memory and Language, 41, 78-104. doi/10.1006/jmla.1999.2638

Flege, J.E., Frieda, A., \& Nozawa, T. (1997). Amount of native-language (L1) use affects the pronunciation in an L2. Journal of Phonetics, 25, 169186. doi.org/10.1006/jpho.1996.0040

Flege, J.E., MacKay, I.A., \& Piske, T. (2002). Assessing bilingual dominance. Applied Psycholinguistics, 23: 567-598. doi.org/10.1017/S014271640200404 6

Freeman, D. \& Johnson, K.E. (1998). Reconceptualizing the knowledgebase of Language Teacher Education.
TESOL Quarterly, 32: 397 - 417. doi:10.2307/3588114

Gee, J.P. (1996). Social linguistics and literacies: Ideology in discourses $\left(2^{\text {nd }}\right.$ ed.). London: Taylor \& Francis.

Genesee, F. (1985). "Second language learning through immersion: A review of U.S. programs." Review of Educational Research, 55 (4): 541561.

https://doi.org/10.3102/00346543055 004541

Ghenghesh, P., (2010). The motivation of L2 learners: Does it decrease with age? English Language Teaching, 3 (1): 128-141. doi.org/10.5539/elt.v3n1p128

Graf, A. (2004). Screening and training intercultural competencies: Evaluating the impact of national culture on intercultural competencies. International Journal of Human Resource Management, 15 (6): 11241148.

doi.org/10.1080/0958519041000167 7340

Hammer, M. R., Bennett, M. J., \& Wiseman, R. (2003). Measuring intercultural sensitivity: The intercultural development inventory. International Journal of Intercultural Relations, 27 (4): 421-443. doi/10.1016/S0147-1767(03)000324

Hedge, T. (2000). Teaching and Learning in the Language Classroom. Oxford: OUP

Jarvis, P. (2004). Adult education and lifelong learning: Theory and practice. London: Routledge Falmer.

Jenkins, J. (2000). The phonology of English as an international language. Oxford: OUP.

Jia, G., Aaronson, D., \& Wu, Y. (2002). Long-term language attainment of bilingual immigrants: Predictive variables and language group differences. Applied Psycholinguistics, 23, 599-621. DOI: 10.1017.S0142716402004058 
Jeon, J. \& Lee, H. (2017). Secondary Teachers' perception on English education policies in Korea. The Journal of Asia TEFL, 14 (1): 47 -63. Retrieved from http://journal.asiatefl.org/

Johnson, J. S., \& Newport, E. L. (1989). Critical period effects in second language learning: The influence of maturational state on the acquisition of English as a second language. Cognitive Psychology, 21 (1): 6099.doi/10.1016/00100285(89)90003-0

Johnson, K. E. (2009). Trends in Second Language Teacher Education. In Anne Burns \& Jack C. Richards (Eds.), Second Language Teacher Education (1 ${ }^{\text {st }}$ ed.). (pp. 20-29). Cambridge: CUP

Kirkpatrick, A. (2006). Which model of English: Native-speaker, nativized or lingua franca? In R. Rubdy \& M. Saraceni (Eds.), English in the world - Global rules, global roles (pp. 7183). London: Continuum.

Kohnert, K., Bates, E., \& Hernandez, A. (1999). Balancing bilinguals: Lexical semantic production and cognitive processing in children learning Spanish and English. Journal of Speech, Language, and Hearing Research, 42: 1400-1413. doi:10.1044/jslhr.4206.1400

Lamb, T. E. (2011). Fragile identities: Exploring learner identity, learner autonomy and motivation through young learners' voices. The Canadian Journal of Applied Linguistics, Special Issue, 14(2): 68-85.

https://journals.lib.unb.ca/index.php/ CJAL/article/view/19858

Lave, J., \& Wenger, E. (1991). Situated Learning. Cambridge: Cambridge University Press.

Leont'ev, A.N. (1981). Problems of the development mind. Moscow: Progress Press.
Littelwood, W. (2005). Foreign and second language learning. Cambridge: Cambridge University Press.

McNeill, A. (1993). Some characteristics of native or non-native speaker teachers of English. Papers presented at Annual International Language in Education Conference, Hong Kong, China. Retrieved from https://books.google.co.id/books?id= 396mBgAAQBAJ\&pg=PA302\&lpg $=$ PA302\&dq $=$ McNeill, + A. $+(1993)$.

Milambiling, J. (1999). Native and nonnative speakers: The view from teacher education. Paper presented at the Annual meeting of the Midwest modern language association, St. Louis, MO.

Retrieved from http://nsuworks.nova.edu/cgi/viewco ntent.cgi article $=1489 \&$ context $=$ tqr

Moran, R. T., Harris, P. R., \& Moran, S. V. (2007). Managing cultural differences: Global leadership strategies for the 21st century. New York: Elsevier.

Norris, E., \& Gillespie, J. (2009). How study abroad shapes global careers: Evidence from the United States. Journal of Studies in International Education, 13 (3): 382-397. doi.org/10.1177/1028315308319740

Olson, C. L., \& Kroeger, K. R. (2001). Global competency and intercultural sensitivity. Journal of Studies in International Education, 5 (2): 116137.doi.org/10.1177/1028315301520 03

Paige, R. M., Jacobs-Cassuto, M., Yershova, Y. A., \& DeJaeghere, J. (2003). Assessing intercultural sensitivity: An empirical analysis of the Intercultural Development Inventory. International Journal of Intercultural Relations, 27 (4): 467486. DOI: $10.1016 / \mathrm{S} 0147-$ 1767(03)00034-8

Pasternak, M., \& Bailey, K. (2004). Preparing nonnative and native English-speaking Teachers: Issues of 
professionalism and proficiency. In L. Kamhi-Stein (Ed.), Learning and teaching from experience: Perspectives on nonnative Englishspeaking professionals (pp. 155-176). Ann Arbor, MI: University of Michigan Press.

Pollard, A., Collins, J., Maddock, M., Simco, N., Swaffield, S., Warin, J. \& Warwick, P. (2005). Reflective Teaching (2nd ed.). London: Continuum.

Rosen, R., Digh, P., Singer, M., \& Phillips, C. (2000). Global literacies: Lessons on business leadership and national cultures. New York: Simon \& Schuster.

Samimy, K. K., \& Brutt-Griffler, J. (1999). To be a native or non-native speaker: Perception of "non-native" students in a graduate TESOL program. In G. Braine (Ed.). Non-native educators in English language teaching (pp. 127144). Mahwah, NJ: Lawrence Erlbaum Associates, Publishers.

Sanders, W. L. (1998). Value added assessment. School Administrator, 11 (55): 24-27.

Sanders, W. L. (2000). Value-added assessment from student achievement data. Cary, NC: Create National Evaluation Institute.

Seidlhofer, B. (1999). Double standards: Teacher education in the expanding circle. World Englishes, 18 (2): 233245. DOI: $\quad 10.1111 / 1467-$ 971X.00136

Sodnomdarjaa, S. (2006). The successful factors for learning foreign language. The Journal of English Education, 33, 213-229.

Stern, H. H. (1983). Fundamental concepts of language teaching. Oxford: Oxford University Press.

Susilo, S. 2015. Curriculum of EFL teacher education and Indonesian qualification framework: a blip of the future direction. Dinamika Ilmu, 15 (1): $11 \quad-24 . \quad$ https://journal.iain- samarinda.ac.id/index.php/dinamika _ilmu/issue/view/15

Ur, P. (1996). A Course in Language Teaching: Practice and Theories. New York: CUP

Vygotsky, L.S. (1978). Mind in Society. Cambridge, M.A.: Harvard University Press.

Wang, S. C. (2010). Chinese language education in the United States: A historical overview and future directions. In J. Chen, C. Wang \& J. Cai (Eds.), Teaching and learning Chinese: Issues and perspectives (pp. 3-32). Charlotte, NC: Information Age Publishing, Inc.

Weber-Fox, C., \& Neville, H. J. (1999). "Functional neural subsystems are differentially affected by delays in 2nd language immersion". In D. Birdsong (Ed.), Second language acquisition and the critical period hypothesis (pp. 23-38). Mahwah, NJ: Erlbaum.

Wragg, E. C. (2005) The Art and Science of Teaching and Learning: The Selected Works of Ted Wragg. London: Routledge Falmer.

Wright, S. P., Hom, S., P, \& Sanders, W., L. (1997). Teacher and classroom context effects on student achievement: Implications for teacher evaluation. Journal of Personal Evaluation in Education, 11, 57-67. https://doi.org/10.1023/A:100799920 4543

Zaharah. 2014. The effect of certification and competence towards teachers' quality in MAN 3 High School Tanggerang, Indonesia. American journal of educational research. 2(5): 267-271. DOI: 10.12691/education$2-5-5$ 